International Journal of Trend in Scientific Research and Development (IJTSRD)

Volume: 3 | Issue: 3 | Mar-Apr 2019 Available Online: www.ijtsrd.com e-ISSN: 2456 - 6470

\title{
Modelling and Analysis of Spark Ignition Carburettor
}

\author{
B. Phanindra Kumar1, Ravi Shankar Sidar², Rohan Kumar², M. Kavya ${ }^{2}$ \\ ${ }^{1}$ Assistant Professor, 2 UG Student \\ 1,2Department of Mechanical Engineering, Guru Nanak Institute of Technology, Rangareddy, Telangana, India
}

How to cite this paper: B. Phanindra Kumar | Ravi Shankar Sidar | Rohan Kumar | M. Kavya "Modelling and Analysis of Spark Ignition Carburettor" Published in International Journal of Trend in Scientific Research and Development (ijtsrd), ISSN: 24566470, Volume-3 | Issue-3, April 2019, pp.1731-1738, URL: https://www.ijtsrd. com/papers/ijtsrd2 3523.pdf

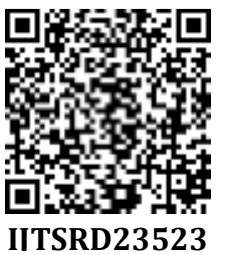

Copyright (C) 2019 by author(s) and International Journal of Trend in Scientific Research and Development Journal. This is an Open Access article distributed under the terms of the Creative Commons

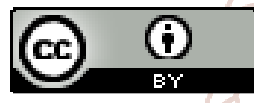
Attribution License (CC BY 4.0) (http://creativecommons.org/licenses/ by/4.0)

\section{INTRODUCTION}

The process of forming a combustible mixture of air and fuel in a proper ratio in the carburettor for combustion process is called as carburetion process. SI engines generally use the volatile liquids. Carburetion process takes place outside the engine cylinder. Various factors affect the combustible mixture of air-fuel ratio like engine speed, Temperature of incoming air, Design of carburettor, in case of high-speed engines less time is available for mixture preparation. In order to achieve the Good quality of air fuel mixture the

\section{ABSTRACT}

Modern passenger vehicles with gasoline engines are provided with different compensating devices for fuel air mixture supply. Even there is a high fuel consumption because of many factors. One of the important factors that affects the fuel consumption is carburettor. The venturi of the carburettor is important that provides a necessary pressure drop in the carburettor device. For a better economy and uniform air fuel supply there is a need to design the carburettor with an effective analytical tool or software. In this work three parameters namely, pressure drop and fuel discharge nozzle angle and the throttle angle will be analysed using the computational fluid dynamics. For this analysis two softwares are used namely CATIA and ANSYS. Whereas CATIA for designing of carburettor and ANSYS for analysis of the carburettor. The results obtained from the soft-wares will be analysed for optimum design of a carburettor and also find out the exact pressure at various throttle angles and choke valve for a proper homogenous air-fuel mixture.

KEYWORDS: Carburettor, pressure drop, Nozzle angle, analysis, CATIA.ANSYS.

\section{METHODOLOGY}

Carburetor is designed by using CATIA and the model is generated by using ANSYS software for analysis. To carry the analysis various, it is introduced. Proper boundary conditions are applied to the model which is designed and various changes in throttle valve and fuel discharge nozzle is observed according to the flow in various conditions and various conditions are been studied. The analysis has been carried at various angles like 30 degrees, 40 degrees, 45 degrees, 50 degrees, 55 degrees, 60 degrees, 65 degrees, 70 degrees, 75 degrees, 80 degrees, 85 degrees.

\begin{tabular}{|c|c|c|c|}
\hline S. No. & Name of the Part & Dimensions & Unit \\
\hline 1 & Inlet diameter & 42 & $\mathrm{~mm}$ \\
\hline 2 & Throat diameter & 27 & $\mathrm{~mm}$ \\
\hline 3 & Outlet diameter & 37 & $\mathrm{~mm}$ \\
\hline 4 & Length of the throat & 5 & $\mathrm{~mm}$ \\
\hline 5 & Length of the inlet section & 51 & $\mathrm{~mm}$ \\
\hline 6 & Length of the outlet section & 51 & $\mathrm{~mm}$ \\
\hline 7 & Fuel nozzle diameter & 2 & $\mathrm{~mm}$ \\
\hline 8 & Total length of carburetor & 122 & $\mathrm{~mm}$ \\
\hline
\end{tabular}

Table 1: Specifications of Carburettor 
International Journal of Trend in Scientific Research and Development (IJTSRD) @ www.ijtsrd.com eISSN: 2456-6470

A carburettor is used designed according to the specifications given in a CATIA soft-ware.

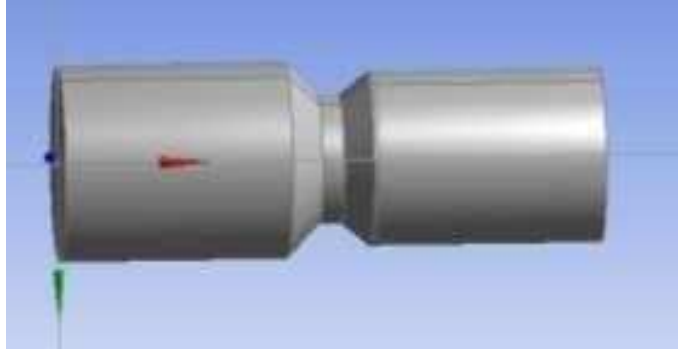

Fig. 1: Venturi considering Choke

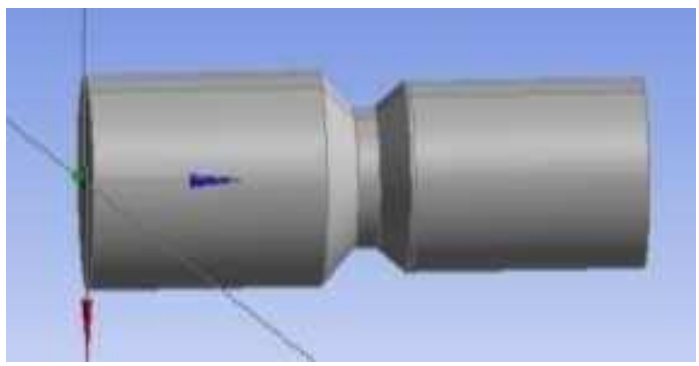

Fig. 2: Venturi considering Throttle

In next stage, meshing of was carried out. Following figure shows the meshed venturi sections.

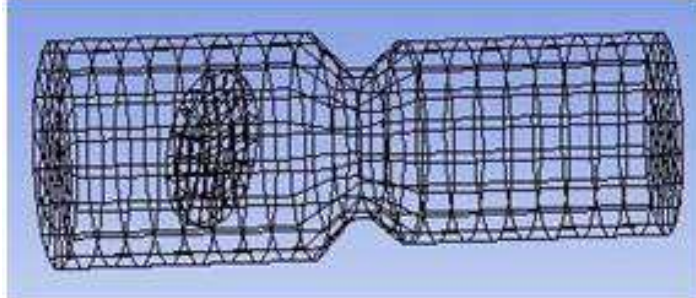

Fig 3: Venturi considering Choke

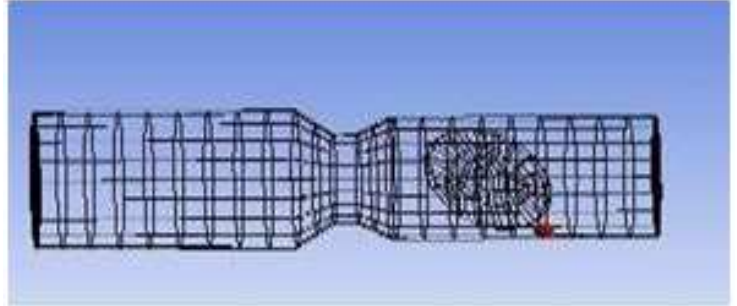

Fig 4: Venturi considering Throttle

Following are the details of meshing parameters.

\begin{tabular}{|c|c|c|c|}
\hline S. No. & Parameter & Venturi considering Choke & Venturi Considering Throttle \\
\hline 1. & Nodes & 1866 & 1874 \\
\hline 2. & Elements & 1463 & 1467 \\
\hline 3. & Mesh Element Type & Coarse & Coarse \\
\hline
\end{tabular}

\section{Table 2: Various Parameters Observed}

In next stage, CFD analysis for different models was carried out, under which pressures and velocities at the exit of throat section and after throttle were investigated.

\section{RESULTS AND DISCUSSION}

frend in Scientific

Present section is devoted to results of the research work and associated discussion made, the details of which are present in upcoming sections

\section{A. Results}

Following are the results of pressures obtained by changing angles of choke.

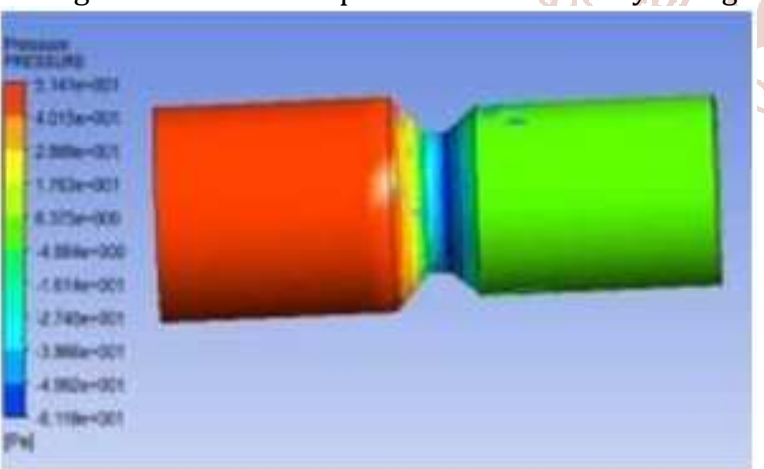

(a)

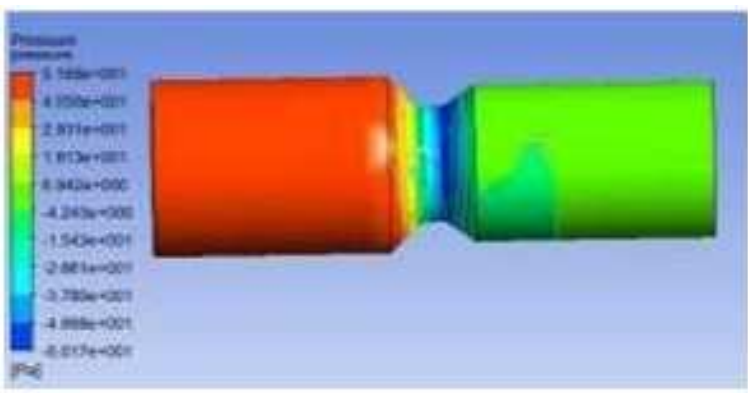

(c)

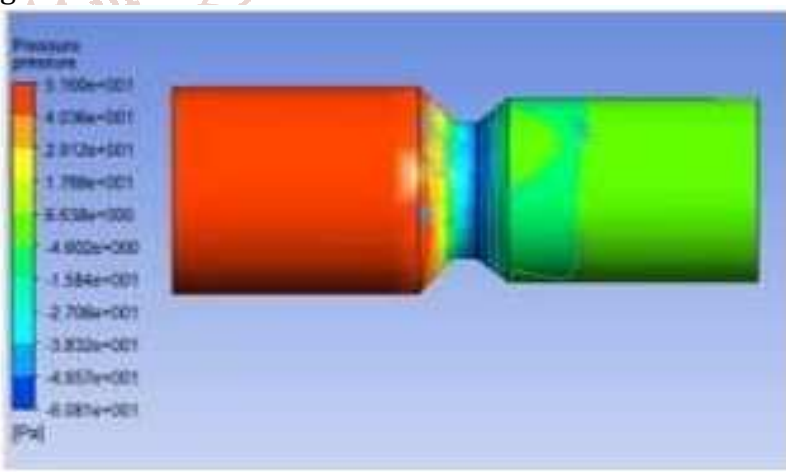

(b)

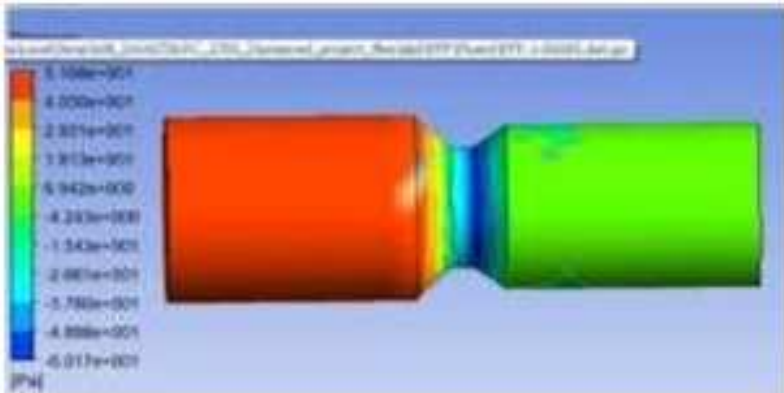

(d) 
International Journal of Trend in Scientific Research and Development (IJTSRD) @ www.ijtsrd.com eISSN: 2456-6470

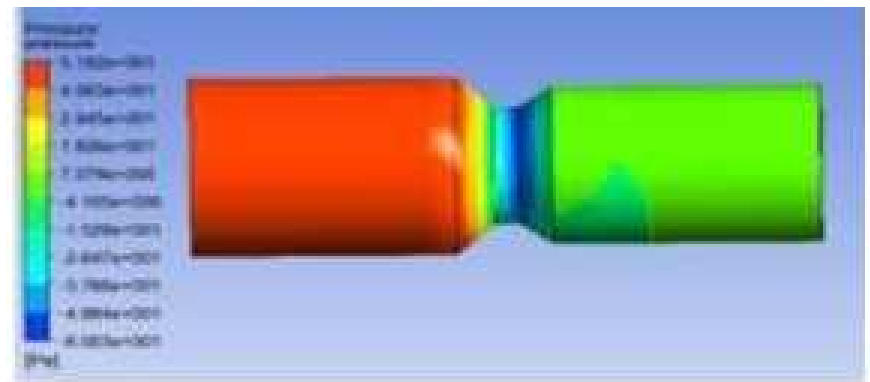

(e)

Fig. 5: Pressure at Different Choke Angles

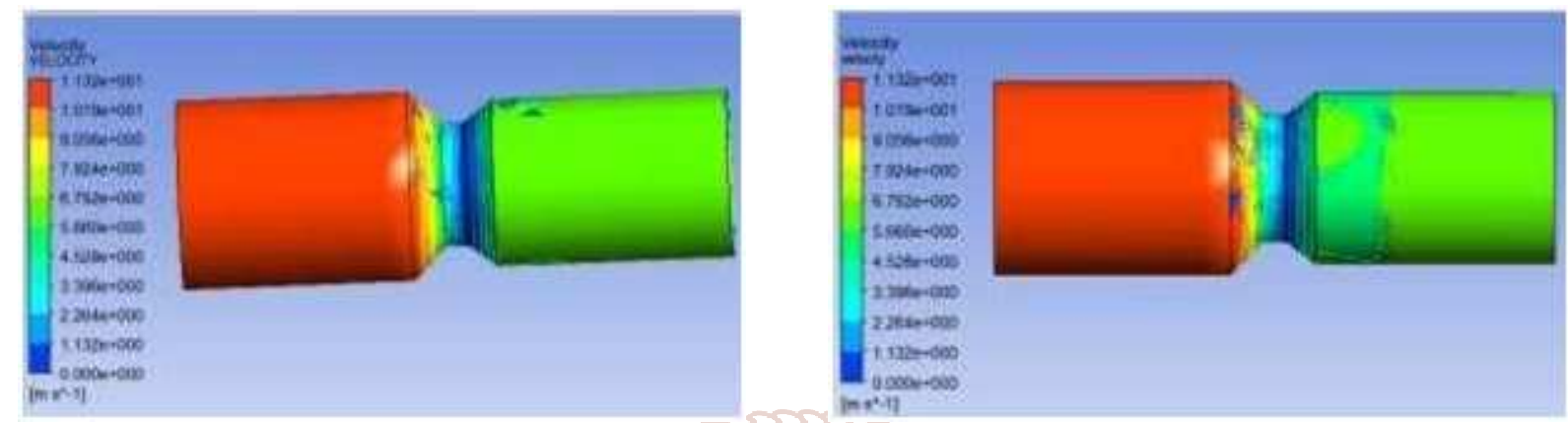

(a)

(b)

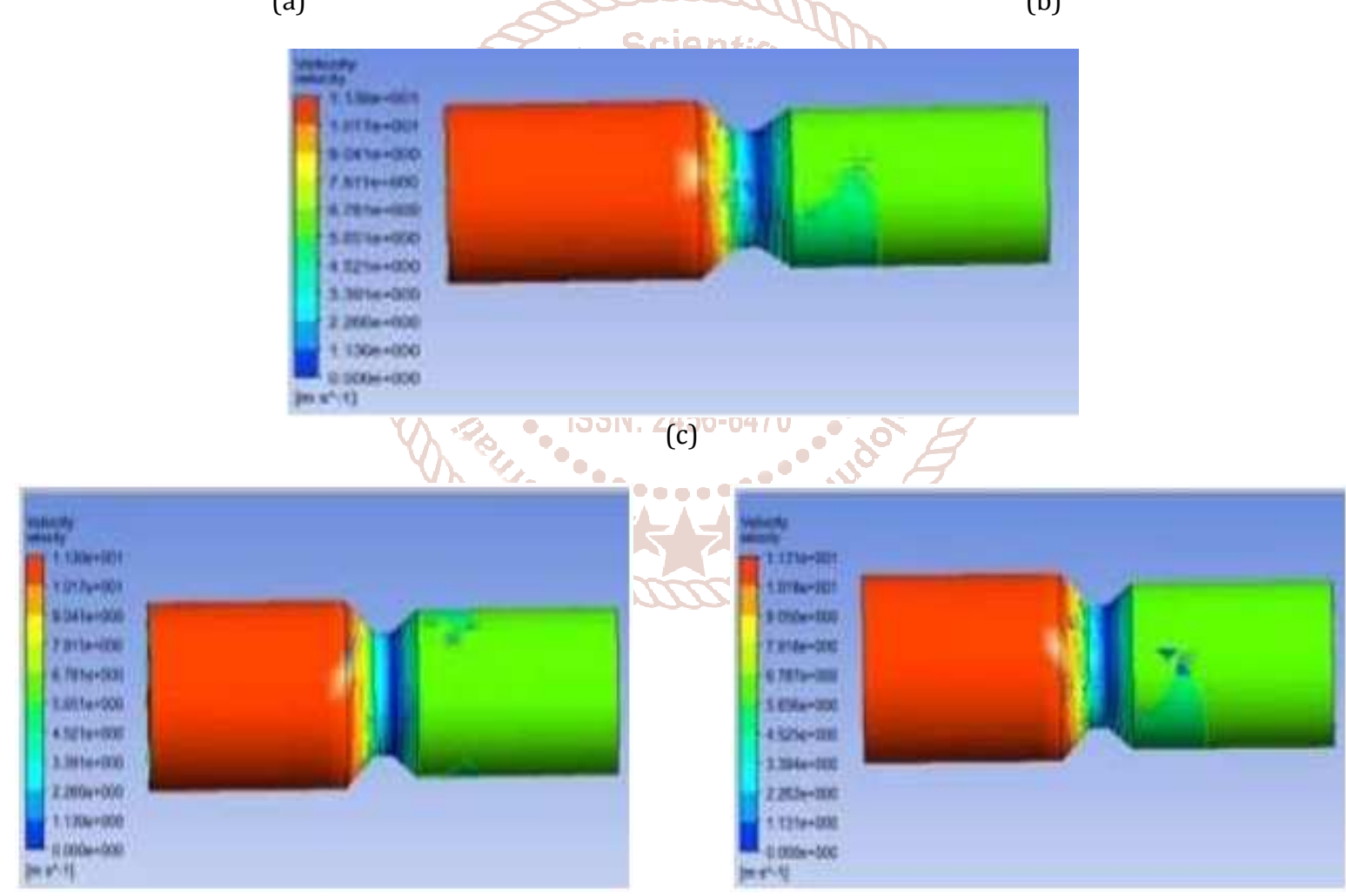

(d)

(e)

Fig. 6: Velocities at Different Choke Angles

\begin{tabular}{|c|c|c|c|}
\hline S. No & Choke Angle (degrees) & Pressure (at throat) (Pa) & Velocity (at throat) (m/s) \\
\hline 1. & 30 & $-4.992 \mathrm{E}+001$ & $1.132 \mathrm{E}+000$ \\
\hline 2. & 45 & $-4.957 \mathrm{E}+001$ & $1.132 \mathrm{E}+000$ \\
\hline 3. & 60 & $-4.896 \mathrm{E}+001$ & $1.130 \mathrm{E}+000$ \\
\hline 4. & 75 & $-4.896 \mathrm{E}+001$ & $1.130 \mathrm{E}+000$ \\
\hline 5. & 90 & $-4.884 \mathrm{E}+001$ & $1.131 \mathrm{E}+000$ \\
\hline
\end{tabular}

Table 3: Summary of Results for Variation in Choke Angles

Negative signs in pressure column show that the gauge pressures are less than operating pressure (101325 Pa). Therefore, in order to get static pressure or absolute pressure, these values were added with operating pressure, and following results were obtained. 
International Journal of Trend in Scientific Research and Development (IJTSRD) @ www.ijtsrd.com eISSN: 2456-6470

\begin{tabular}{|c|c|c|}
\hline S. No & Choke Angle (degrees) & Static Pressure (at throat) (Pa) \\
\hline 1. & 30 & 101275.1 \\
\hline 2. & 45 & 101275.4 \\
\hline 3. & 60 & 101276 \\
\hline 4. & 75 & 101276 \\
\hline 5. & 90 & 101276.2 \\
\hline
\end{tabular}

Table 4: Static Pressure for different Choke angles

\section{Results of pressures obtained by changing throttle angles}

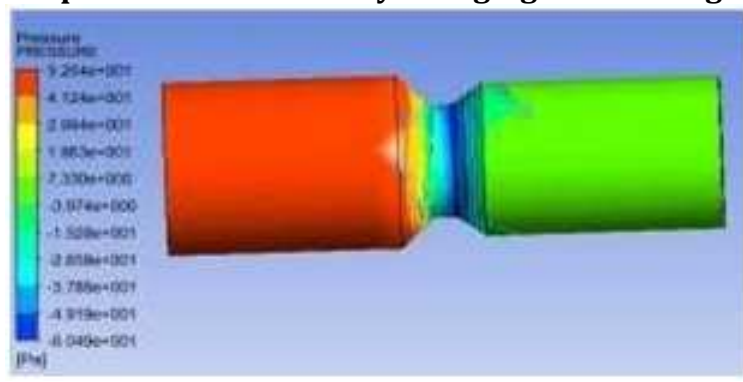

(a) 30Degrees

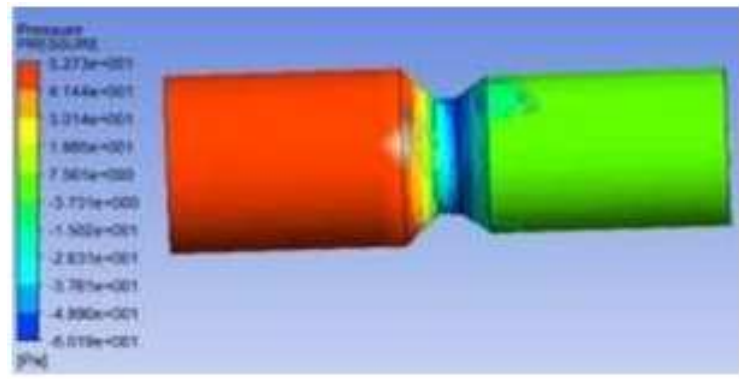

(c) 40Degrees

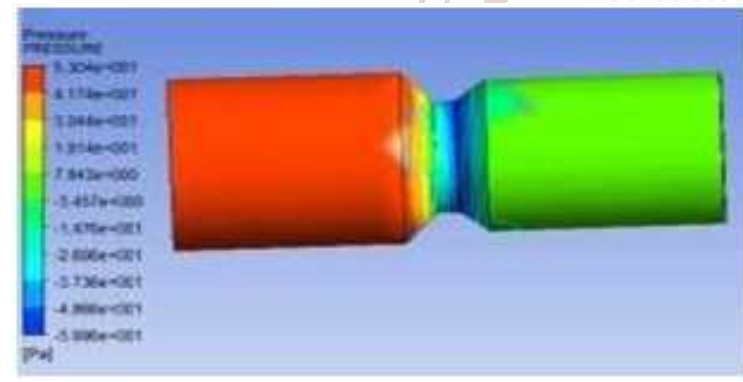

(e) 50Degrees

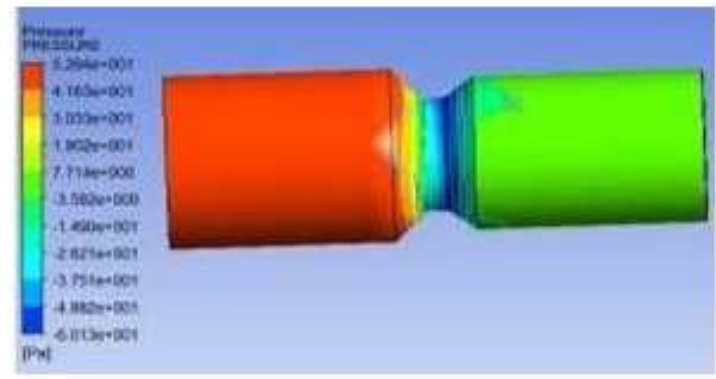

(g) 60Degrees

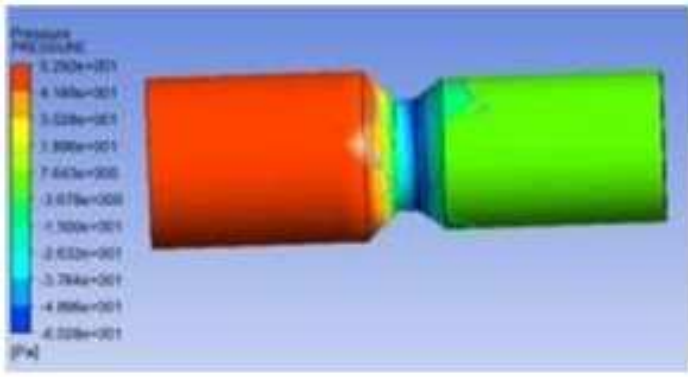

(i) 70Degrees

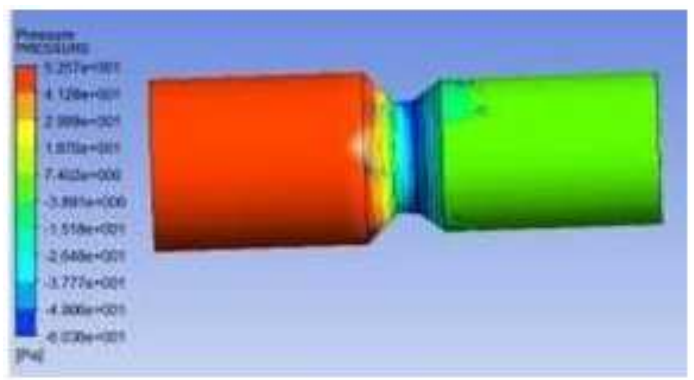

(b) 35Degrees

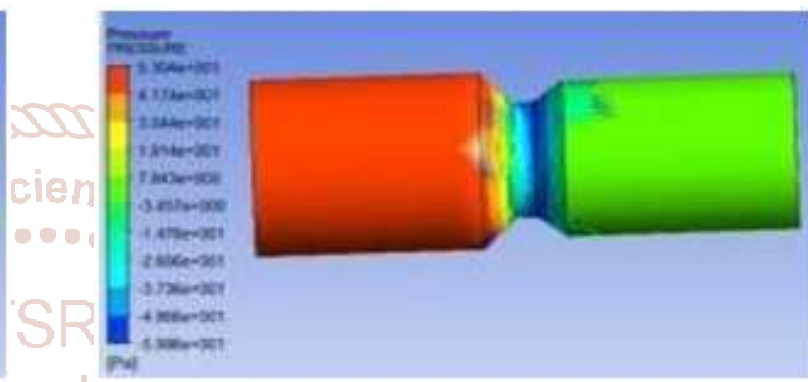

(d) 45Degrees

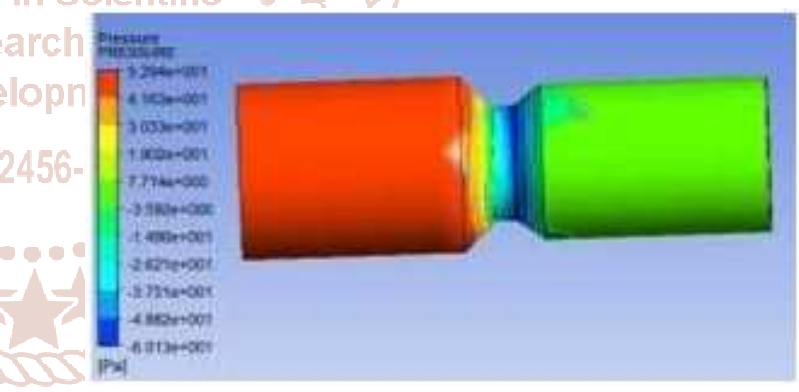

(f)55Degrees

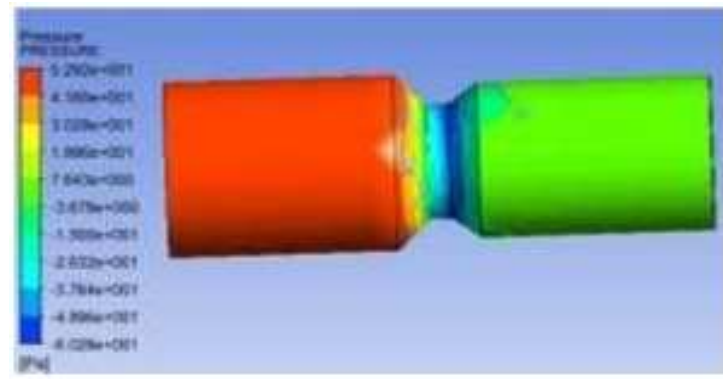

(h) 65Degrees

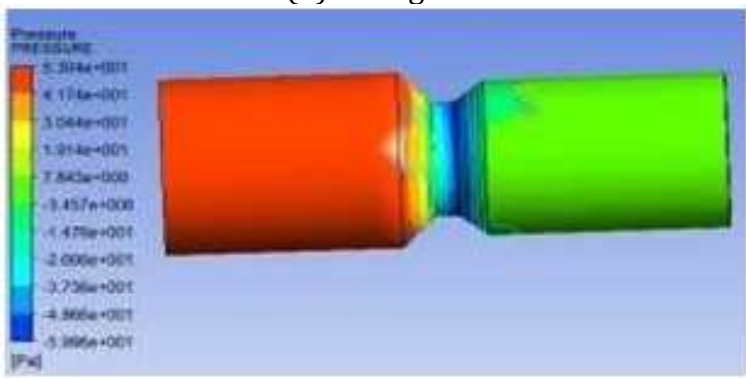

(j) 75Degrees 
International Journal of Trend in Scientific Research and Development (IJTSRD) @ www.ijtsrd.com eISSN: 2456-6470

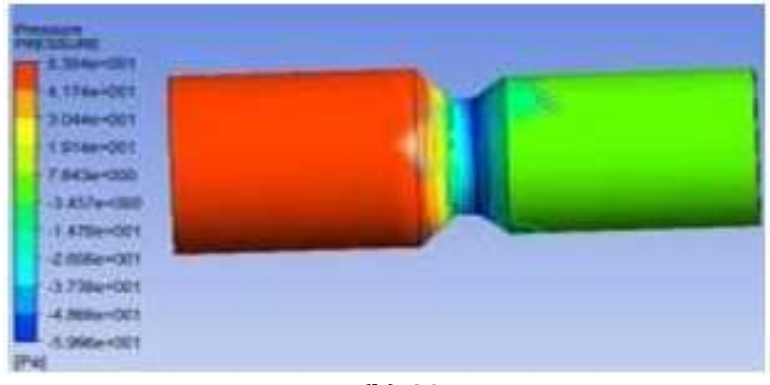

(k) 80Degrees

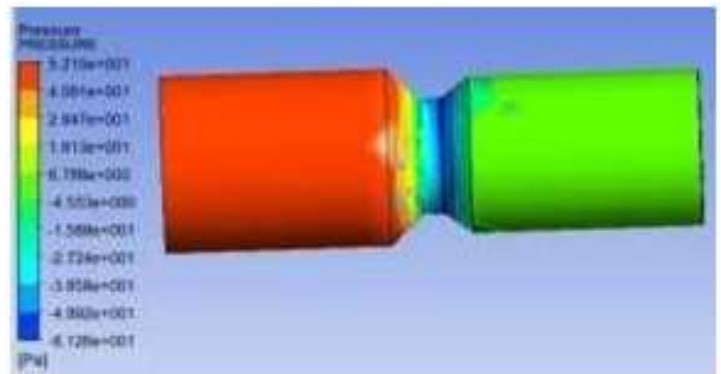

(l) 85Degrees

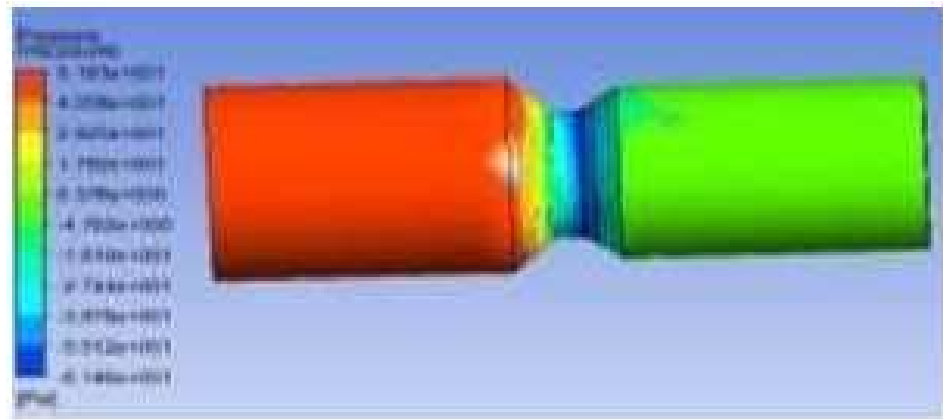

90Degrees

Fig.7: Pressure at different Throttle Angles

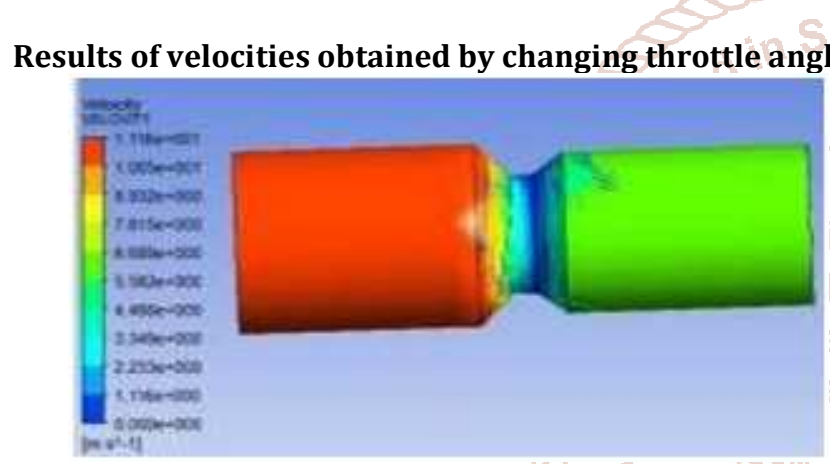

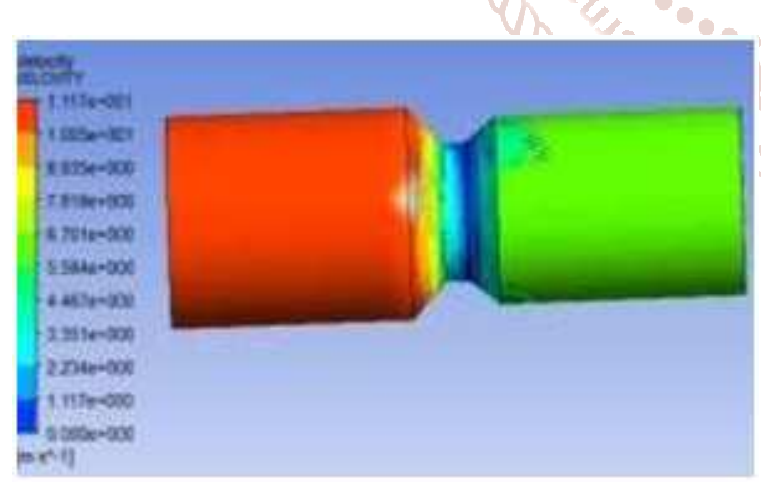

(c) 40Degrees

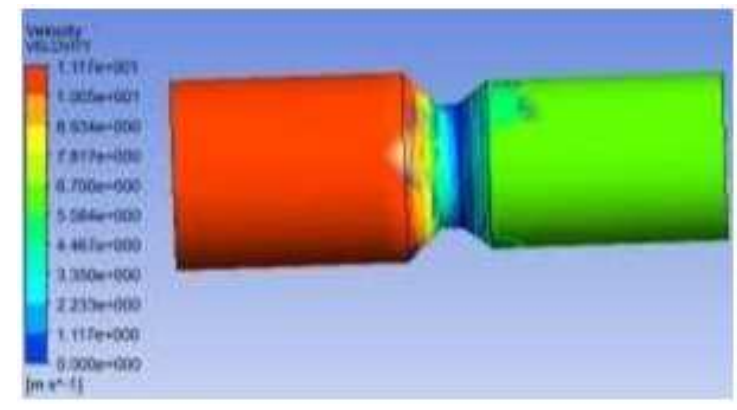

(e) 50Degrees

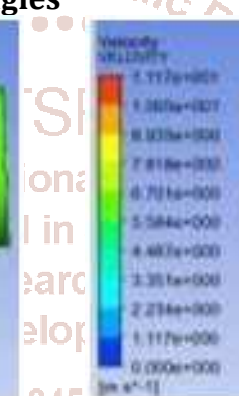

well

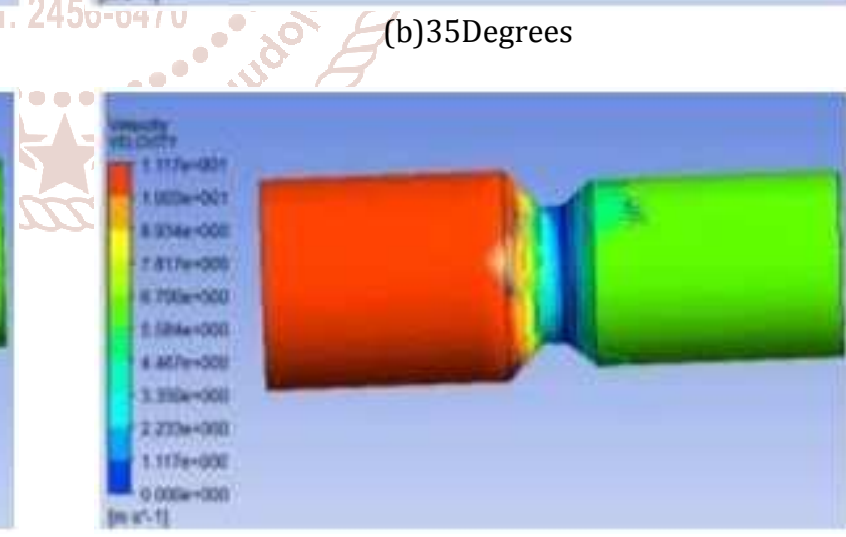

(d) 45Degrees

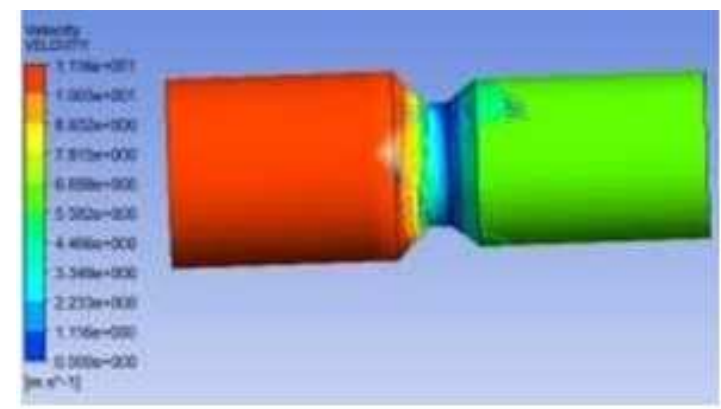

(f) 55Degrees 
International Journal of Trend in Scientific Research and Development (IJTSRD) @ www.ijtsrd.com eISSN: 2456-6470

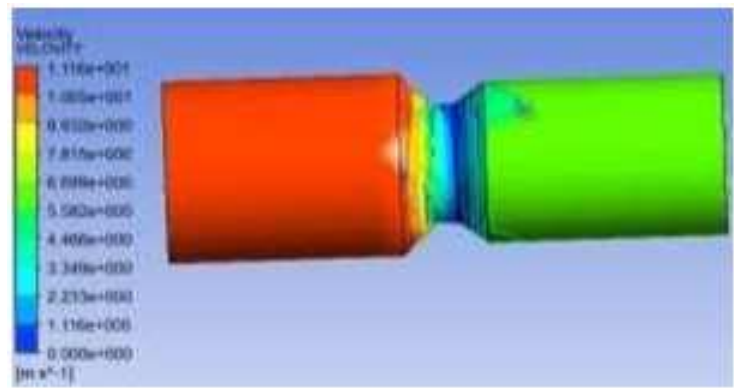

(g) 60Degrees

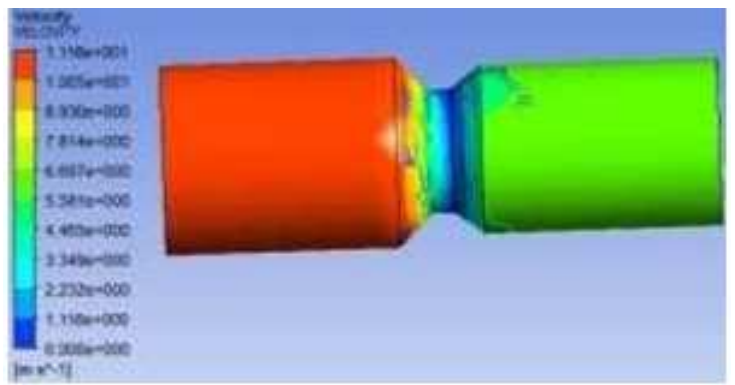

(i) 70Degrees

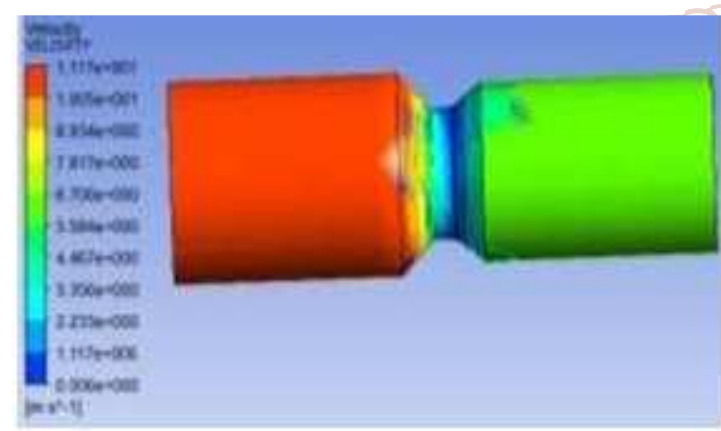

(k) 80Degrees

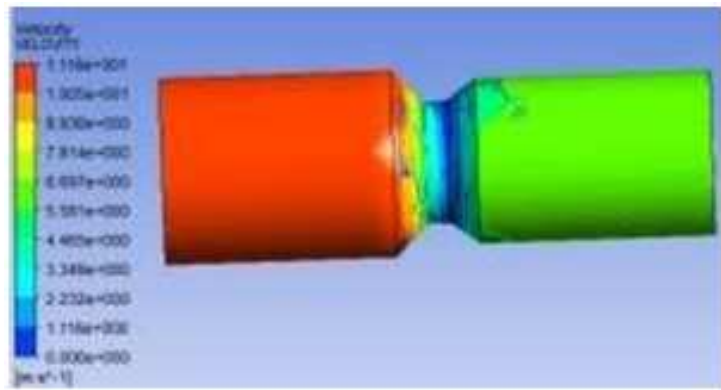

(h) 65Degrees

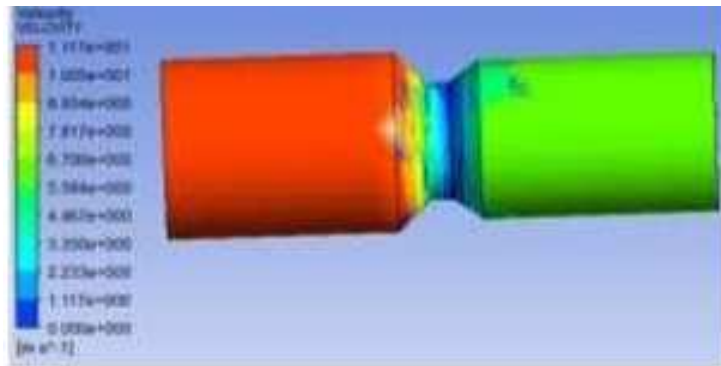

(j) 75Degrees

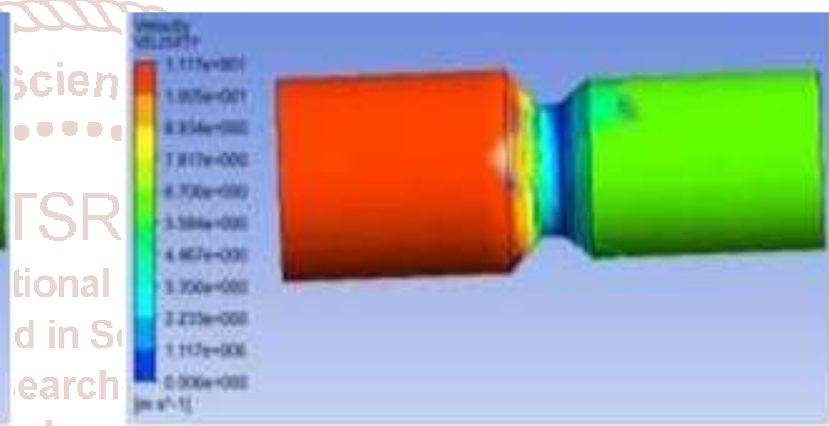

(1) 85 Degrees

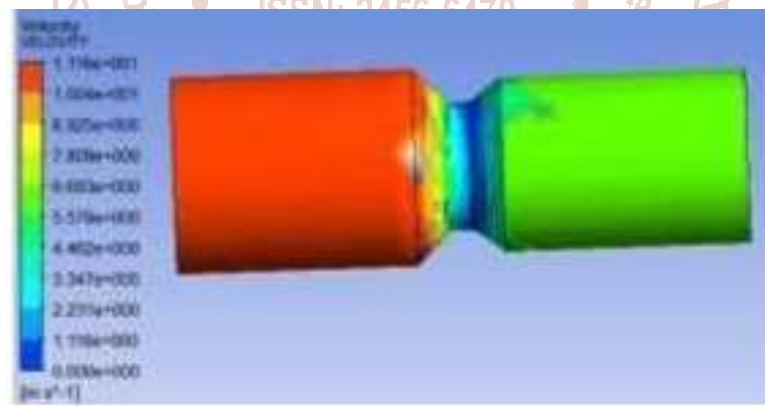

(m) 90 Degrees

Fig.8: Velocities at different Throttle angles

\begin{tabular}{|c|c|c|c|}
\hline S. No & Throttle Angle (degrees) & Pressure (after throttle) (Pa) & Velocity (after throttle) (m/s) \\
\hline 1. & 30 & $-3.974 \mathrm{E}+000$ & $5.582 \mathrm{E}+000$ \\
\hline 2. & 35 & $-3.891 \mathrm{E}+000$ & $5.584 \mathrm{E}+000$ \\
\hline 3. & 40 & $-3.371 \mathrm{E}+000$ & $5.584 \mathrm{E}+000$ \\
\hline 4. & 45 & $-3.457 \mathrm{E}+000$ & $5.584 \mathrm{E}+000$ \\
\hline 5. & 50 & $-3.457 \mathrm{E}+000$ & $5.584 \mathrm{E}+000$ \\
\hline 6. & 55 & $-3.592 \mathrm{E}+000$ & $5.582 \mathrm{E}+000$ \\
\hline 7. & 60 & $-3.592 \mathrm{E}+000$ & $5.582 \mathrm{E}+000$ \\
\hline 8. & 65 & $-3.678 \mathrm{E}+000$ & $5.581 \mathrm{E}+000$ \\
\hline 9. & 70 & $-3.678 \mathrm{E}+000$ & $5.581 \mathrm{E}+000$ \\
\hline 10. & 75 & $-3.457 \mathrm{E}+000$ & $5.584 \mathrm{E}+000$ \\
\hline 11. & 80 & $-3.457 \mathrm{E}+000$ & $5.579 \mathrm{E}+000$ \\
\hline 12. & 85 & $-4.533 \mathrm{E}+000$ & $5.578 \mathrm{E}+000$ \\
\hline 13. & 90 & $-4.762 \mathrm{E}+000$ & \\
\hline
\end{tabular}

Table 5: Variations of pressure and velocity with respect to Throttle Angles 
In this case also negative signs in pressure column show that the gauge pressures are less than operating pressure (101325 $\mathrm{Pa}$ ). Therefore, in order to get static pressure or absolute pressure, these values were added with operating pressure, and following results were obtained.

\begin{tabular}{|c|c|c|}
\hline S. No & Throttle Angle (degrees) & Static Pressure (after throttle) (Pa) \\
\hline 1. & 30 & 101321.026 \\
\hline 2. & 35 & 101321.109 \\
\hline 3. & 40 & 101321.629 \\
\hline 4. & 45 & 101321.543 \\
\hline 5. & 50 & 101321.543 \\
\hline 6. & 55 & 101321.408 \\
\hline 7. & 60 & 101321.408 \\
\hline 8. & 65 & 101321.322 \\
\hline 9. & 70 & 101321.322 \\
\hline 10. & 75 & 101321.543 \\
\hline 11. & 80 & 101321.543 \\
\hline 12. & 85 & 101320.467 \\
\hline 13. & 90 & 101320.238 \\
\hline
\end{tabular}

Table 6: Static pressure for different throttle angles

\section{B. Discussion}

We know that at throat section of the venturi, a requirement of minimum pressure and maximum velocity exists. This is because, at throat section due to lower pressure fuel reaches, and if the velocity of air at this section is higher, rapid formation along with rapid removal of air fuel mixture from that vicinity will take place. Considering this fact, chock angle which offers lowest pressure with greatest velocity should be considered. In research analysis, chock angles 30 degree shows the least value of static pressure as compared to other angles. In case of velocity value for this angle, greatest values out of all combinations, is obtained. Second best option is 45-degree chock angle, because at this choke angle, velocity is same as that of 30-degree choke angle and pressure is somewhat higher than previous case. Above this angle, one can find considerable deviations the values of static pressure and velocity of air.

Considering trend line also, one can analyze that out of the available options best choke angle is 30 degree. Below figures shows hypothetical and actual Otto cycles.

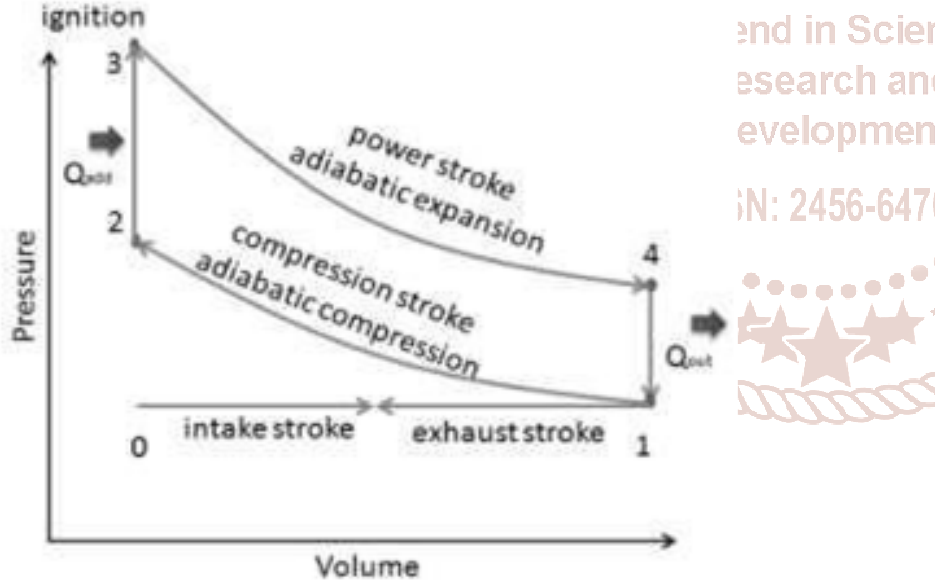

Fig. 9: Hypothetical Cycle

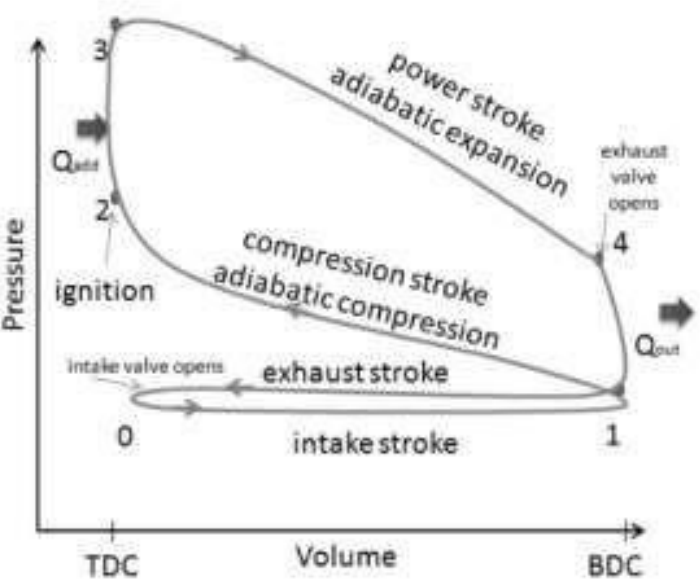

Fig. 10: Actual Otto Cycle

\section{CONCLUSION}

Present conclusion tells about conclusions drawn, limitations and future scope of the research, the details of which are presented in upcoming sections. Following conclusions are being drawn from the research work.

$>$ At throat section, static pressure increases and velocity decreases with increase in choke angle;

$>$ After throttle valve, both static pressure and velocity decrease with increase in throttle angle;

$>$ Out of analyzed options, best angles for choke valve are 30 degree and 45 degree, respectively and Out of analyzed options, best angles for throttle valve are 40degree, 45 degree and 50 degree respectively.

\section{FUTURE SCOPE}

Based on limitations, future scope of the research can be dictated through following points.
$>$ A vast research considering complete assembly of carburetor can be initiated;

$>$ A detailed research involving a broader set of properties can be undertaken and

$>$ A more detailed research considering all the possible combinations of angles, length ratios, diameters, and other parameters can be initiated.

\section{REFERENCES}

[1] Elfasakhany Ashraf (2015). Investigations on the effects of ethanol methanol gasoline blends in a sparkignition engine: Performance and emissions analysis. Engineering Science and Technology. https://www.academia.edu/11883083/PERFORMANC E_AND_EMISSION_CHARACTERISTICS_OF_SPARK_IGNI TION_ENGINE 
[2] Krishna A.S. \& Mallikarjuna J.M. (2016), parametric analysis of a 4-stroke GDI engine using CFD. Alexandria Engineering.

https://www.sae.org/publications/technicalpapers/content/2013-01-1085/

[3] Kumar Jay, Singh Jaspreet, Kansal Harsh, Narula Gursimran Singh, and Singh Prabhjot (2014). CFD Analysis of Flow using Venturi. International Journal of Research in Mechanical Engineering and Technology, 4 (2), 214. https://www.researchgate.net/publication/32955727 9_CFD_Analysis_of_Flow_Through_Venturi_1

[4] Sharma T.K. (2015) performance and emission characteristics of the thermal barrier coated SI engine by adding argon inert gas to intake mixture. Journal of advance research 6(6), 819-826. https://www.ncbi.nlm.nih.gov/pmc/articles/PMC4642 $172 /$

[5] Suleiman M.Y. Ayob, M.R. \& meran I. (2013).Performance of single cylinder spark ignition engine fueled by LPG. Procedia Engineering53,579-589. https://www.sciencedirect.com/science/article/pii/S1 877705813001938

[6] Ronald J Adrian, "Particle -Imaging Techniques for Experimental Fluid Mechanics" Annu. Rev. Fluid Mech. $1991.23:$ 261-304. https://www.annualreviews.org/doi/abs/10.1146/an nurev.fl.23.010191.001401
[7] Douglas G Janisch patented work on producer gas carburetor; US Patent 5070851 December 101991. https://www.researchgate.net/publication/26047796 6_Analysis_and_Optimal_Design_of_a_Producer_Carbur etor

[8] Sridhar G, Shridhar H V, Dassapa S, Paul P J, Rajan N K S and Mukunda H S, "Development of Producer Gas Engine", Published in Institute of mechanical engineers, 2005.

https://www.researchgate.net/publication/26047796 6_Analysis_and_Optimal_Design_of_a_Producer_Carbur etor

[9] Klimstra J "Carburetors for Gaseous Fuels -on Air to Fuel ratio, Homogeneity and Flow restriction. SAE paper 892141. http://www.ijesr.org/admin/upload_journal/journal_J. A.\%20Aditya\%20\%20\%20\%20\%201oloct13esr.pdf

[10] Versteeg $\mathrm{H} \mathrm{K}$, and Malalasekara W An introduction to CFD-The finite volume method, 1995 (Longman Scientific and Technical). Bangalore". http://ftp.demec.ufpr.br/disciplinas/TM702/Versteeg_ Malalasekera_2ed.pdf

[11] Anil T R, Tewari P G, and Rajan N K S “ An approach for Designing of Producer Gas Carburetor for Application in Biomass based Power Generation Plants proceedings of the national conference of Natcon 2004. https://www.ugc.ac.in/mrp/paper/MRP-MAJORMECH-2013-24734-PAPER.pdf 